\title{
Cervical Warty Carcinoma
}

National Cancer Institute

\section{Source}

National Cancer Institute. Cervical Warty Carcinoma. NCI Thesaurus. Code C40191.

A human papillomavirus-related cervical squamous cell carcinoma characterized by the presence of a warty surface and koilocytotic atypia. 